International Research Journal of Management, IT \& Social Sciences
Available online at https://sloap.org/journals/index.php/irjmis/
Vol. 5 No. 5 September 2018, pages: $1 \sim 16$
ISSN: 2395-7492
https://doi.org/10.21744/irjmis.v5n5.275

\title{
The Impact of Financial Ratios towards Profit Changes
}

\author{
Victor Pattiasina ${ }^{a}$ \\ Fajar Rina Sejati ${ }^{b}$ \\ Yohanes Cores Seralurin ${ }^{c}$ \\ Ridolof Wenand Batilmurik ${ }^{\mathrm{d}}$ \\ Mutiara Austin Al Aziz ${ }^{\mathrm{e}}$
}

Article history:

Received: 1 March 2018

Revised: 5 July 2018

Approved: 2 August 2018

Published: 8 August 2018

\section{Keywords:}

Current Ratio;

Profit Change;

Return on Asset;

Price Earnings Ratio;

Total Assets Turnover;

\begin{abstract}
A Company will be interested in investors if its financial report is relevant and reliable. The relevance and reliable financial report can be reflected in the Asset Number and Liability Report on a Financial Position Statement (Balance Sheet). The success of a company can be measured by company ability, which is reflected in management performance. A company's performance parameter that commonly used is profit change. Profit itself is important to the company since this will be decision basis for investors to invest in the company. Profit Change reflected in financial statements using fair value will bring benefits to market participants, as the financial statements itself reflects the real market value. This research aims to examine the influence of Current Ratio, Total Asset Turnover, Price Earnings Ratio, and Return on Asset, towards profit changes that based on fair value. Research problem discussed in this study was how CR, TATO, PER, and ROA influence profit changes of a property company, real estate, and building construction, in period 2013-2016. The study was based on fair value. The population was company property, real estate, and building construction, that have been listed in Indonesia Stock Exchange (ISE). It consisted of 63 companies. Through Purposive Sampling technique, 12 companies were selected to be examined. Data analysis was conducted through a multiple linear regression analysis. Results of multiple linear regression analysis showed that the CR, TATO, and PER had an influence towards Profit Changes, while ROA had no influence toward it.
\end{abstract}

2395-7492@ Copyright 2018. The Author. This is an open-access article under the CC BY-SA license (https://creativecommons.org/licenses/by-sa/4.0/) All rights reserved.

\section{Author correspondence:}

Victor Pattiasina,

Faculty of Economics, Yapis University Papua, Jayapura, Indonesia

Email address: victor_pattiasina@uniyap.ac.id

\footnotetext{
${ }^{a}$ Faculty of Economics, Yapis University Papua, Jayapura, Indonesia

${ }^{\mathrm{b}}$ Faculty of Economics, Yapis University Papua, Jayapura, Indonesia

${ }^{c}$ Faculty of Economics, Yapis University Papua, Jayapura, Indonesia

${ }^{\mathrm{d}}$ Department of Business Administration, Kupang State Polytechnic, Indonesia

${ }^{\mathrm{e}}$ Faculty of Economics, Yapis University Papua, Jayapura, Indonesia
} 


\section{Introduction}

A financial statement is the main accounting reports that communicate information to authority so the authority can conduct economic analysis, and future economic interpreting. The statement could apply the correct accounting information in order to develop a set of analysis techniques that based on the published financial statement (Hanafi \& Halim, 2016). A company's performance parameter that commonly used is profit.

The next year profit earned by a company is unpredictable. Sometimes it is high, sometimes it is low. The profit changes will affect investment decisions of potential investors who will infuse capital in the company (Argiles \& Slof, 2000). Profit itself is an indicator to find whether the financial performance of a company is increasing or decrease. The changes of increasing and decreasing will affect financial policy for the next business activity, such as dividends policy, debt service payments, allowance, investment, etc. It maintains the continuity of the company activities. This is normal, as investors are always expecting a high rate investment return from any company.

Through the fair value method, company financial statement that made by the company itself will reflect the real company conditions. Thus, the profit or loss of assets and liabilities of the company will also be seen in the financial statements. This research was intended to do further examination about empirical findings regarding financial ratios, particularly, regarding its usefulness in predicting future profits. Accounting profit was selected since profit itself reflects the company's performance. A company has got a good performance or not, can be examined through the profit gained Hadi, et. al. (2018), Suardana, et. al. (2018), Lisa, et. al. (2018).

This research is different to previous researches since the financial performance variables used in this research were current ratio, debt to total asset ratio, Total Assets Turnover, and Return on Assets. In other words, this research has got a high novelty. The objective of this research is to examine Current Ratio, Total Assets Turnover, Price Earnings Ratio, and Return on Assets, either partially or simultaneous, towards Profit Change that based on the fair value

\section{Research Methods}

In this section, before presenting the method of this research, the researchers present a theoretical review and hypothesis as the part of the research method applied. The theoretical review displayed is about the financial statement, fair value, profit change, and financial ratios. Next, similar previous researches are also be presented here. Finally, the researches present research method.

\section{The Theoretical Review and Hypothesis}

\section{Financial Statement}

Generally, there are three forms of basic financial statements issued by a company, namely: Balance sheet, Income statements, and Cash flow statements (Christiano et al, 2014) The statements, basically, intend to report company activities such as investment activity, funding activity, operational activity, and to evaluate the success of the company's strategy in achieving goals (Edsel, et al. 2017).

\section{Fair Value}

Theoretically, the fair value is believed as a more relevant method than the historical cost approach. The fair value reflects investors risk which has been adjusted with the expected future cash flows (Dechow \& Shakespeare, 2010). Therefore, this is hoped to be more appropriate than any other approaches. However, there are some practical problems with fair value accounting. On the other hand, the fair value measurement could be very complex. As there is no included market price in an active market, the fair value measurement is based on subjective assumptions and can be manipulation subject.

\section{Profit Change}

In the operational basis, profit is the difference between earned income and costs for a period. According to Ikatan Akuntan Indonesia (2009), profit is the increase in economic benefits during the accounting period, in the form of infusion or the addition of assets, or decrease in liabilities, that impacts the increase of equity that is not derived from the role of capital contribution. Change in profit is the difference between the profit obtained from a period before and a period after. 
Financial Ratios

Liquidity Ratio

a. Current Ratio

Current Ratio $=\frac{\text { current asset }}{\text { current debt }}$

Hanafi \& Halim (2016) Stated that current Ratio measures the ability of a company in paying short-term debt by using current assets (assets which will be turned into cash within one year or one business cycle).

\section{b. Quick Ratio}

$$
\text { Quick Ratio }=\frac{\text { current asset-stock }}{\text { current debt }}
$$

The quick ratio indicates the ability of the most liquid current assets and is able to cover the debt. The larger quick ratio the better it is (Harahap, 2013).

\section{Activity Ratio}

a. The Average Age of Accounts Receivable

The average age of accounts receivable $=\frac{\text { debt }}{\text { selling } / 365}$

The average age of accounts receivable examines how long it takes to pay off accounts receivable (accounts receivable into cash change). The longer average accounts receivable, the bigger fund in accounts receivable. The average age of accounts receivable can be calculated through two stages, namely by calculating the turnover of receivables and then calculate the average age of accounts receivable (Karuniawati \& Handayani, 2014).

b. Inventory Turnover

Inventory Turnover $=\frac{\text { begining capital }}{\text { stock }}$

High Inventory turnover indicates the increasing supply of rotating in one year. It also indicates the effectiveness of inventory management. In contrast, a low inventory turnover indicates management lack, such as a lack of an effective inventory control.

c. Fixed Assets Turnover

$$
\text { Fixed Assets Turnover }=\frac{\text { selling }}{\text { total fixed Asset }}
$$

Fixed Assets Turnover ratio examines how extensive a company is able to generate sales based on the fixed assets owned by the company. It is conducted by showing the effectiveness of the company in using fixed assets. The higher this ratio, the more effective fixed assets used.

d. Total Assets Turnover Ratio

$$
\text { Total Asset Turnover }=\frac{\text { Selling }}{\text { total assets }}
$$

Total Assets Turnover ratio measures the effectiveness of the use of the total assets. A high ratio indicates a good management, while low contrast ratio indicates a bad management, in which its strategies, marketing, and investment should be evaluated.

Pattiasina, Pattiasina, V., Sejati, F. R., Seralurin, Y. C., Batilmurik, R. W., \& Aziz, M. A. A. (2018). The impact of financial ratios towards profit changes. International Research Journal of Management, IT and Social Sciences, 5(5), 1-16. https://doi.org/10.21744/irjmis.v5n5.275 
Solvency Ratio

a. The ratio of Total Debt to Total Assets

Total Debt to Total Assets $=\frac{\text { total deb }}{\text { Total assets }}$

The ratio of total debt to total assets is calculating how much funding is provided by the lender. A high ratio means a company has used high financial leverage.

b. Times Interest Earned Ratio

Times Interest Earned $=\frac{\text { Earnings Before Interest and Taxes }(E B I T)}{\text { interest }}$

The ratio of times interest earned (TIE) measures a company's ability in paying the debt by pre-interest tax profit.

c. Fixed Charged Converge Ratio

Fixed Charged Converge $=\frac{\text { EBIT }+ \text { rent expense }}{\text { interest }+ \text { rent expense }}$

The ration of fixed charged converge examines rent. Even though the rent is not a debt, it is a fixed load that reduces company debt capacity. The fixed load will have the same effect as interest expenses.

\section{Profitability Ratio}

a. Profit Margin

$$
\text { Profit Margin }=\frac{\text { net income }}{\text { selling }}
$$

High-profit margin indicates the ability of the company in producing a high profit on certain sales levels. The lowprofit margin indicates a low sale for certain fees level or the fees is too high for certain sales level or a combination of both.

b. Return on Assets

$$
\text { Return on Assets }=\frac{\text { net income }}{\text { current asset }}
$$

Total of Return on Assets (ROA) examines the ability of the company generates profit based on certain assets level.

c. Return on Equity

$$
\text { Return on Equity }=\frac{\text { net income }}{\text { stock equity }}
$$

Return on Equity (ROE) examines the ability of the company generates earnings based on the share capital and is a measure of the profitability of shareholders ' point of view.

\section{Market Ratio}

a. Price Earnings Ratio

Price Earnings Ratio $=\frac{\text { market price per sheet }}{\text { net income per sheet }}$

Price Earnings Ratio (PER) shows a comparison between the price of the stock market and the price of prime offered compared to the income earned. High Price Earnings Ratio (PER) shows a high expectation of investors to the future company's achievements.

b. Dividend Yield

$$
\text { Dividend Yield }=\frac{\text { Dividen per sheet }}{\text { market price per sheet }}
$$


The dividend yield is a part of total return which will be acquired by investors. The other return part is capital gain. It is obtained from the positive difference between the selling price and the purchase price. If the difference is negative, a capital loss will happen.

c. Dividend Payout
Dividend Payout $=\frac{\text { Dividen per sheet }}{\text { net income per sheet }}$

Dividend payout ratio examines section earning (income) paid as a dividend for investors. Other undistributed parts will be in re-invested to the company.

\section{Previous Research}

Pangkong, Lambey, and Affandi (2017) stated that based on fair value, Total Assets Turnover had an influence towards profit changes while Current Ratio had not got any effect on the changes. Their research results also showed that Current Ratio (CR) affected positive changes (Sujarwo \& Asyik, 2015). Susanti and Widyawati (2016) stated that Return on Assets (ROA) had got a significant influence and positive towards profit changes. Total Assets Turnover (TATO) had not got significant influence toward profit changes (Hermanda \& Amanah, 2015); as well Return on Assets (ROA) had not got significant and positive influence (Wibowo \& Pudjiati, 2011).

\section{Road Map}

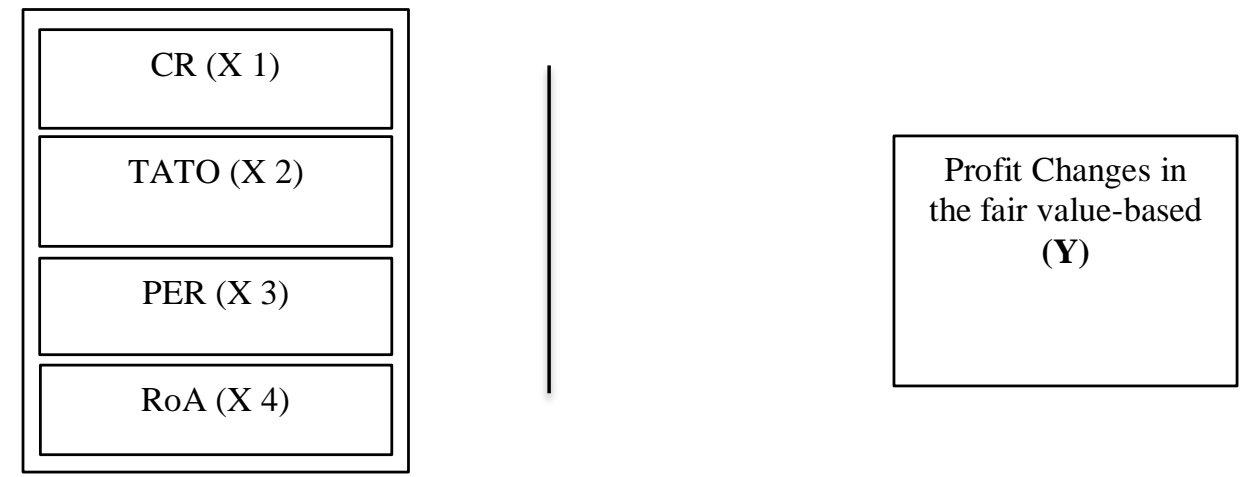

Figure 1. The Conceptual Framework

Hypothesis

\section{Current Ratio Influence towards profit changes in fair value-based}

In previous studies, there were some researchers who applied the Current Ratio to predict future profit changes (see. Hermanda \& Amanah, 2015). The results showed that Current Ratio did not affect profit change, whereas, in other research that examined agricultural company, in period 2010-2013, it was stated that Current Ratio had a significant ability to predict future profit change. The hypothesis proposed in this study is: Current Ratio has got influence towards profit changes, based on fair value (H1).

\section{The influence of Total Asset Turnover towards profit change based on fair value changes}

In the previous research, researchers stated that Total Asset Turnover had got influence to profit changes. In contrary, in the other research, researchers stated that the Total Asset Turnover had not got any influence. The hypothesis proposed in this study is: Total Assets Turnover, based on fair value, has got profit changes (H2).

Pattiasina, Pattiasina, V., Sejati, F. R., Seralurin, Y. C., Batilmurik, R. W., \& Aziz, M. A. A. (2018). The impact of financial ratios towards profit changes. International Research Journal of Management, IT and Social Sciences, 5(5), 1-16. https://doi.org/10.21744/irjmis.v5n5.275 
The influence of Price Earnings Ratio towards profit changes in the fair-value-based.

For investors, the higher Price Earnings Ratio, the more profit growth is expected. The previous researchers, about Price to Earnings Ratio (PER) variable, it was stated that PER had no significant influence on the company's share price towards the plantation sector in Indonesia Stock Exchange (IDX) (see. Tavip \& Helen, 2014). The hypothesis proposed in this study is: Price Earnings Ratio effects profit changes the fair value- based (H3).

Influence of Return on Asset towards profit changes, based on fair value.

Previous researchers stated that Return on Assets had got significant influence and positive towards profitable growth. In contrary, other researchers stated that the return on asset had got negative influence towards profit change of the Indonesia stock exchange company. The hypothesis proposed in this study is: Return on Asset, based on fair value, has to influence towards profit changes $(\mathrm{H} 4)$.

\section{The influence of simultaneous}

The influence of Current Ratio, Total Assets Turnover, Price Earnings Ratio, and Return on Assets, based on fair value, changes the profit simultaneously. The independent variable in this study concludes that there is a simultaneous relationship between Current Ratio variable, Total Assets Turnover variable, Return on Assets variable towards profits change. This statement has been reinforced by Sujarwo and Asyik (2015). Based on their research, they stated that variable CR, DER, TATO, and ROA had influenced profit change simultaneously. The hypothesis proposed in this study is: Current Ratio, Total Assets Turnover, Price Earnings Ratio, and Return on Assets, based on fair Value, have influenced profit changes simultaneously (H5).

This research was associate quantitative research. It was conducted to examine whether there was the influence of CR, TATO, PER, and ROA towards profit changes in fair value based or not (Suliyanto, 2016). The sample was Property Sub Sectors Company, Real Estate, and Building Construction Company that was listed on the Indonesia Stock Exchange (ISE). Quantitative research emphasizes examining theories through variables measurements research with numbers, and performing data analysis through statistical procedures (see Noch \& Husen, 2015; Noch \& Rasyid, 2012).

The population used in this research was a financial statement of Property Sub Sectors Company, Real Estate and Building Construction Company that were listed in the ISE in the year 2016 (see www.idx.co.id). All of them were 63 companies. Data used in this research was secondary data, i.e. financial statements of financial position reports, and income statements of Property Sub Sectors Companies, Real Estate, and Building Construction Company that were listed in the ISE, during the period of 2013-2016. The sample selection criteria were as follows: 1) The companies have been listed on the ISE in research years of 2013-2016. 2) The companies have published audited annual financial statements. 3) The companies have got complete data in accordance with research variables, namely Current Ratio, Total Assets Turnover, Price Earnings Ratio, and Return on Assets.

\section{Dependent Variable}

Change in profit is the difference between the profit obtained from a period before and a period after. Profit used is net profit after interest and taxes.

$$
\begin{aligned}
& \quad \Delta Y_{i t}=\frac{Y_{i t}-Y_{i t-1}}{Y_{i t-1}} \\
& \Delta Y_{i t} \quad=\text { Profit Changes } \\
& Y_{i t} \quad=\text { Profit of certain companies at certain periods } \\
& Y_{i t-1}=\text { Profit of certain companies in the previous period }
\end{aligned}
$$

\section{Independent Variable}

\section{a. Current Ratio (CR)}

Current Ratio shows the extent of how far current assets cover current liabilities. The larger comparison between current assets and current liabilities, the ability of companies in covering the short-term liabilities is higher. Mathematically, liquidity ratio can be calculated by the following formula: 


$$
\text { Current Ratio }=\frac{\text { current asset }}{\text { current debt }}
$$

b. Total Asset Turnover (TATTO)

Total Assets Turnover shows Total Assets Turnover that measured by the volume of sales. In other words, it examines how far the ability of all assets generates sales. Mathematically, the activity ratio can be calculated by the formula as follows:

$$
\text { Total Asset Turnover }=\frac{\text { selling }}{\text { Total fixed asset }}
$$

c. Price Earnings Ratio (PER)

The company that expects to grow (has good prospects), has to have a high Price Earnings Ratio (PER). In the other side, low Price Earnings Ratio reveals that the company has slow growth of Price Earnings Ratio (PER). Mathematically, the market ratio can be calculated as follows:

$$
\text { Price Earnings Ratio }=\frac{\text { market price per sheet }}{\text { net income per sheet }}
$$

\section{d. Return on Asset (ROA)}

Return on asset (ROA) examines how much net profit has been obtained by the company, measured by the asset. Mathematically, the profitability ratio can be calculated by the following formula:

$$
\text { Return on Assets }=\frac{\text { net income }}{\text { current asset }}
$$

Types of data used in this research are quantitative data, that taken from numbers in financial statements. Data gained was then processed in order to examine the hypothesis proposed in the study. The secondary data was obtained from 1) the financial statements sample, the year 2013-2016 and 2) annual company report sample, the year 20132016. The required data consists of secondary data, that published by the IDX www.idx.co.id for data through the company's financial reporting in the year 2013 to 2016.

Next, the researchers used descriptive statistics analysis. It was used to give information about the research variables such as the Current Ratio (CR), Total Assets Turnover (TATO), Price Earnings Ratio (PER), Return on Assets (ROA) and profits (PL).

Researchers also applied multiple regression test. Beside regression analysis measuring relationship strength between two or more variables, the regression analysis is also showing relationship direction between the dependent variable and independent variable (Warnoso, 2011). The regression analysis model in the study is as follows:

In which:

$$
P L=a+\beta_{1} C R_{1}+\beta_{2} T A T O_{2}+\beta P E R_{3}+\beta_{4} R O A_{4}+e
$$

$\begin{array}{ll}\mathrm{PL} & =\text { Change In Profit } \\ \mathrm{a} & =\text { A constant } \\ \beta_{1}, \beta_{2}, \beta_{3}, \beta_{4} & =\text { Regression Coefficient } \\ C R_{1} & =\text { Current Ratio } \\ \mathrm{TATO}_{2} & =\text { Total Assets Turnover } \\ \mathrm{PER}_{3} & =\text { Price Earnings Ratio } \\ R O A_{4} & =\text { Return on Assets } \\ \mathrm{e} & =\text { Error Term }\end{array}$

Hypothesis Testing

a. T-Test

The t-test is a test which basically shows how far an explanatory variable or independent individually influences an explanation of dependent variable variation (Ghozali, 2016). Test of the significance of Individual Parameters (t-

Pattiasina, Pattiasina, V., Sejati, F. R., Seralurin, Y. C., Batilmurik, R. W., \& Aziz, M. A. A. (2018). The impact of financial ratios towards profit changes. International Research Journal of Management, IT and Social Sciences, 5(5), 1-16. https://doi.org/10.21744/irjmis.v5n5.275 
test) is as follows: 1) If the probability or significance $\alpha>0.05$ then the independent variable, individually, has no effect towards the dependent variable. 2) If significance a $<0,05$ then the independent variable, individually, has an effect towards the dependent variable.

b. F Test

The F-test is the test that shows whether all independent variables that included in the model have an influence towards the dependent variables.

c. The Determination Coefficient R2

The value of the determination coefficient is between zero and one. A small value of R2 means the ability of independent variables, in explaining the various independent variables, is very limited. The point is, the Determination coefficient R2 measures how far the model is capable of explaining the dependent variations.

\section{Results and Analysis}

\subsection{The Description of Research Variable}

Using Current Ratio formula, Current Ratio (CR) level of Property Company, real estate, and building construction that have been provided as research sample during the year 2013-2016, and current ration is shown as follows:

Table 1

Variable CR description

\begin{tabular}{|c|c|c|c|c|c|}
\hline \multirow{2}{*}{ Code } & \multicolumn{4}{|c|}{ Years } & \multirow{2}{*}{ Mean } \\
\hline & 2013 & 2014 & 2015 & 2016 & \\
\hline ADHI & 1,39 & 1,34 & 1,56 & 1,29 & 1,40 \\
\hline APLN & 1,68 & 1,83 & 1,39 & 1,07 & 1,49 \\
\hline ASRI & 0,75 & 1,14 & 0,72 & 0,90 & 0,88 \\
\hline BAPA & 2,69 & 2,09 & 2,08 & 2,18 & 2,26 \\
\hline BEST & 2,53 & 2,26 & 3,92 & 3,29 & 3,00 \\
\hline BSDE & 2,60 & 2,06 & 2,73 & 2,94 & 2,58 \\
\hline CTRA & 1,36 & 1,43 & 1,57 & 1,88 & 1,56 \\
\hline KIJA & 2,87 & 5,04 & 6,35 & 6,45 & 5,17 \\
\hline LPKR & 4,95 & 5,17 & 6,91 & 5,45 & 5,62 \\
\hline PWON & 1,30 & 1,41 & 1,22 & 1,33 & 1,31 \\
\hline TOTL & 0,16 & 1,30 & 1,26 & 1,28 & 1,00 \\
\hline WIKA & 1,09 & 1,12 & 1,19 & 1,48 & 1,22 \\
\hline WSKT & 1,42 & 1,31 & 1,16 & 1,17 & 1,26 \\
\hline
\end{tabular}

Above table shows the average level of the current highest ratio during the year of 2013-2016 occurred at PT Lippo Karawaci Tbk. It was 5.62. This condition reflects the company's ability to meet its short-term obligations was very good. While the average of Current Ratio - lowest level during the year 2013-2016, owned by PT Alam Sutra Reality Tbk, was 0.88 . This condition indicates the company was not able to meet its short-term obligations, using its current assets.

\section{The Description of Total Asset Turnover Variable}

Using Total Asset Turnover (TATO) formula, Total Assets Turnover level of Property Company, real estate, and building construction, which have been provided as research sample during the year 2013-2016, is shown as follows: 
Table 2

The description of TATO variable

\begin{tabular}{|c|c|c|c|c|c|}
\hline \multirow{2}{*}{ Code } & \multicolumn{4}{|c|}{ Years } & \multirow{2}{*}{ Mean } \\
\hline & 2013 & 2014 & 2015 & 2016 & \\
\hline ADHI & 1,01 & 0,83 & 0,56 & 0,55 & 0,74 \\
\hline APLN & 0,25 & 0,22 & 0,24 & 0,23 & 0,24 \\
\hline ASRI & 0,26 & 0,21 & 0,15 & 0,13 & 0,19 \\
\hline BAPA & 0,23 & 0,26 & 0,14 & 0,19 & 0,20 \\
\hline BEST & 0,40 & 0,23 & 0,15 & 0,16 & 0,23 \\
\hline BSDE & 0,25 & 0,20 & 0,17 & 0,17 & 0,20 \\
\hline CTRA & 0,25 & 0,27 & 0,29 & 0,23 & 0,26 \\
\hline KIJA & 0,33 & 0,33 & 0,32 & 0,27 & 0,31 \\
\hline LPKR & 0,21 & 0,31 & 0,22 & 0,23 & 0,24 \\
\hline PWON & 0,33 & 0,23 & 0,25 & 0,23 & 0,26 \\
\hline TOTL & 1,03 & 0,85 & 0,80 & 0,81 & 0,87 \\
\hline WIKA & 0,94 & 0,78 & 0,69 & 0,50 & 0,73 \\
\hline WSKT & 1,10 & 0,82 & 0,47 & 0,39 & 0,69 \\
\hline
\end{tabular}

Source: Data processed by the researcher, 2018

Above table shows the highest average level of Total Assets Turnover occurred in PT Persada Tbk. It was 0.87. This condition reflects PT Persada Tbk. as the most effective company in managing the entire assets, while a company with lowest Total Asset Turnover level has occurred in Natural Silk Reality PT Tbk. It was indicated by examining the lowest average of Total Asset Turnover acquisition. Amount 0.19 indicated that Natural Silk Reality PT Tbk. was a company with low ability in managing the entire assets.

\section{Description of Variable Price Earnings Ratio}

Using the formula of Price Earnings Ratio, the Price Earnings Ratio level of the company property, real estate, and building construction, which have been provided as a research sample during the year 2013-2016, is as follows:

Table 3

The description of PER variable

\begin{tabular}{|c|c|c|c|c|c|}
\hline \multirow{2}{*}{ Code } & \multicolumn{4}{|c|}{ Years } & \multirow{2}{*}{ Mean } \\
\hline & 2013 & 2014 & 2015 & 2016 & \\
\hline ADHI & 6,70 & 16,92 & 10,55 & 23,63 & 14,45 \\
\hline APLN & 5,18 & 8,06 & 8,05 & 6,44 & 6,93 \\
\hline ASRI & 9,64 & 10,03 & 11,30 & 13,60 & 11,14 \\
\hline BAPA & 8,70 & 4,88 & 23,92 & 18,75 & 14,06 \\
\hline BEST & 5,72 & 17,99 & 13,40 & 7,29 & 11,10 \\
\hline BSDE & 8,39 & 8,55 & 16,01 & 18,81 & 12,94 \\
\hline CTRA & 11,72 & 14,37 & 17,38 & 23,84 & 16,83 \\
\hline KIJA & 38,68 & 15,02 & 15,07 & 13,82 & 20,65 \\
\hline LPKR & 16,87 & 9,09 & 44,02 & 18,58 & 22,14 \\
\hline PWON & 11,48 & 9,86 & 18,93 & 16,29 & 14,14 \\
\hline TOTL & 8,78 & 23,10 & 10,96 & 13,07 & 13,98 \\
\hline WIKA & 17,02 & 37,15 & 24,02 & 14,88 & 23,26 \\
\hline WSKT & 10,60 & 28,32 & 18,52 & 15,26 & 18,17 \\
\hline
\end{tabular}

Pattiasina, Pattiasina, V., Sejati, F. R., Seralurin, Y. C., Batilmurik, R. W., \& Aziz, M. A. A. (2018). The impact of financial ratios towards profit changes. International Research Journal of Management, IT and Social Sciences, 5(5), 1-16. https://doi.org/10.21744/irjmis.v5n5.275 
The above table shows the average level of the Price Earnings Ratio during 2013-2016. The highest average occurred on PT Wijaya Karya Tbk. The amount was 23.26. This condition reflected that the company had a good ability to meet the needs of investors by making a very good stock price. The lowest average occurred on PT Agung Podomoro Land Tbk. The amount was 6.93 .

\section{The Description of Return on Assets Variable}

Using the formula of return on asset, level of return on asset towards Property Company, real estate, and building construction, which have been provided as a research sample in the year 2013-2016, is as follows:

Table 4

The description of ROA variable

\begin{tabular}{cccccc}
\hline \multirow{2}{*}{ Code } & \multicolumn{5}{c}{ Years } \\
& 2013 & 2014 & 2015 & 2016 & Mean \\
\hline ADHI & 0,04 & 0,03 & 0,03 & 0,02 & 0,03 \\
APLN & 0,05 & 0,04 & 0,05 & 0,04 & 0,04 \\
ASRI & 0,06 & 0,07 & 0,04 & 0,03 & 0,05 \\
BAPA & 0,03 & 0,04 & 0,01 & 0,01 & 0,02 \\
BEST & 0,22 & 0,11 & 0,05 & 0,06 & 0,11 \\
BSDE & 0,13 & 0,14 & 0,07 & 0,05 & 0,10 \\
CTRA & 0,07 & 0,08 & 0,07 & 0,04 & 0,06 \\
KIJA & 0,01 & 0,05 & 0,03 & 0,04 & 0,03 \\
LPKR & 0,05 & 0,08 & 0,02 & 0,03 & 0,05 \\
PWON & 0,12 & 0,15 & 0,07 & 0,09 & 0,11 \\
TOTL & 0,10 & 0,07 & 0,07 & 0,07 & 0,08 \\
WIKA & 0,05 & 0,05 & 0,04 & 0,04 & 0,04 \\
WSKT & 0,04 & 0,04 & 0,03 & 0,03 & 0,04 \\
\hline \multicolumn{5}{c}{ Source: Data processed by the researcher, 2018} \\
\hline
\end{tabular}

The above table shows the average rate of Return on Assets. As can be seen, the highest amount occurred at PT Bekasi Fajar Industrial Tbk and PT Pakuwon Jati Tbk. Their amount was 0.11 . The condition reflected the ability of the companies, in generating net profit using the entire wealth, was very good. While the company with the lowest capability in generating the profit was PT Bekasi Asri Beginners Tbk. Its average during the year 2013-2016 was only 0.02 .

\section{Description of Independent Variable}

Using the formula of profit change, the level of companies' profit change could be reflected. The profit change level of a property company, real estate, and building construction, that have been provided as research sample in the year 2013-2016, is as follows:

Table 5

The description of PC

\begin{tabular}{|c|c|c|c|c|c|}
\hline \multirow{2}{*}{ Code } & \multicolumn{4}{|c|}{ Years } & \multirow{2}{*}{ Mean } \\
\hline & 2013 & 2014 & 2015 & 2016 & \\
\hline ADHI & 0,91 & $-0,20$ & 0,42 & $-0,32$ & 0,20 \\
\hline APLN & 0,11 & 0,06 & 0,14 & $-0,16$ & 0,03 \\
\hline ASRI & $-0,27$ & 0,32 & $-0,42$ & $-0,25$ & $-0,15$ \\
\hline BAPA & 0,12 & 0,40 & $-0,83$ & 0,51 & 0,05 \\
\hline BEST & 0,58 & $-0,47$ & $-0,46$ & 0,59 & 0,06 \\
\hline
\end{tabular}




\begin{tabular}{cccccc}
\hline BSDE & 0,96 & 0,37 & $-0,41$ & $-0,13$ & 0,20 \\
CTRA & $-0,66$ & $-0,27$ & 0,03 & 0,33 & $-0,14$ \\
KIJA & $-0,73$ & 2,82 & $-0,17$ & 0,29 & 0,55 \\
LPKR & 0,20 & 0,97 & $-0,67$ & 0,20 & 0,18 \\
PWON & 0,48 & 1,29 & $-0,46$ & 0,27 & 0,39 \\
TOTL & 0,17 & $-0,22$ & 0,16 & 0,16 & 0,07 \\
WIKA & 0,19 & 0,19 & $-0,05$ & 0,63 & 0,24 \\
WSKT & 0,44 & 0,40 & 1,05 & 0,73 & 0,65 \\
\hline \multicolumn{5}{c}{ Source: Data processed by the researcher, 2018 }
\end{tabular}

From the above table, it can be seen that the highest average level of profit changes occurred in PT Waskita Karya Tbk. The amount was 0.65 . This condition reflected that the level of the company's earnings was growing. In another side, the lowest profit growth occurred at PT Natural Silk Reality Tbk. Its amount was only 0.14. In general, it also reflected the growth rate of companies' profit for the year 2013-2016 was getting down.

\section{Multiple Analysis}

Multiple linear regression was applied in this study in order to examine whether there was influence between the free variables of Current Ratio (CR), Total Assets Turnover (TATO), Price Earnings Ratio (PER), and Return on Assets (ROA) towards variables bound of profit change (PC), as well to know its influence.

Table 6

The linear coefficient (the dependent variable PL)

\begin{tabular}{llll}
\hline \multirow{2}{*}{ Variable } & \multicolumn{3}{c}{ PL } \\
\cline { 2 - 4 } Constant & $-0,059$ & Unstandardized Coefficients & Significant \\
CR & 0,293 & 2,060 & 0,045 \\
TATO & 0,284 & 2,033 & 0,048 \\
PER & $-0,356$ & $-2,496$ & 0,016 \\
ROA & 0,160 & 1,151 & 0,256 \\
Total & & & 52 \\
Observation & & & \\
R2 & 0,226 & & \\
Adjusted R Square & 0,16 & & \\
F-value & 3,431 & & \\
SIG F & 0,015 & & \\
\hline
\end{tabular}

Source: SPSS data processing output 21

$R^{2}$ Test

The Determination Coefficient $\left(\mathrm{R}^{2}\right)$ aims to measure how far the model was able in explaining the dependent variable variance (Noch \& Husen, 2015). The value of determination coefficient was between zero and one. A small value of $\mathrm{R}^{2}$ means the ability of independent variables in explaining the variable variance is very limited. The value that approximates one means the independent variables have provided almost all the information needed to predict the dependent variable variance. If adjusted $\mathrm{R}^{2}$ is negative, then the value of the adjusted $\mathrm{R}^{2}$ is considered as zero.

Pattiasina, Pattiasina, V., Sejati, F. R., Seralurin, Y. C., Batilmurik, R. W., \& Aziz, M. A. A. (2018). The impact of financial ratios towards profit changes. International Research Journal of Management, IT and Social Sciences, 5(5), 1-16. https://doi.org/10.21744/irjmis.v5n5.275 
Table 7

Model Summary

\begin{tabular}{|l|r|r|r|r|}
\hline Model & \multicolumn{1}{|c|}{$\mathrm{R}$} & R Square & \multicolumn{1}{c|}{$\begin{array}{c}\text { Adjusted R } \\
\text { Square }\end{array}$} & $\begin{array}{r}\text { STD. The error } \\
\text { of the Estimate }\end{array}$ \\
\hline 1 &, $475 \mathrm{a}$ &, 226 &, 160 &, 55791446 \\
\hline
\end{tabular}

a. Predictors: (Constant), ROA, TATO, CR, PER

b. Dependent Variable: PL

Based on the above table (table 10), the value of determination coefficient (R2) was 0.160 or $16 \%$. This means, the profit change variables of a property company, real estate, and building construction, can only be explained $16 \%$ through the variability of Current Ratio (CR), Total Assets Turnover (TATTOOS), Price Earnings Ratio (PER) and Return on Assets (ROA). The rest of the $84 \%$ needs to be explained through other variables that are not included in this regression.

\section{FTest}

The F-test statistics testing is the testing of the overall regression (Aprilia \& Andayani, 2016). This will show whether the whole independent variable has an influence towards the dependent variable.

Table 8

ANOVA $^{\mathrm{a}}$

\begin{tabular}{|ll|r|r|r|r|c|}
\hline \multicolumn{1}{|l|}{ Model } & Sum of Squares & DF & Mean Square & F & SIG. \\
\hline \multirow{4}{*}{1} & Regression & 4,272 & 4 & 1,068 & 3,431 &, $015 \mathrm{~b}$ \\
& Residual & 14,630 & 47 &, 311 & & \\
& Total & 18,902 & 51 & & & \\
\hline
\end{tabular}

a. Dependent Variable: PL

b. Predictors: (Constant), ROA, TATO, CR, PER

Based on above table (table 11), regression calculation obtained F-count of 3,431 and sig $0.015<(\alpha) 0,05$ or by significant less than 0,05 or in the amount of 0,015. It is concluded that modeling built, namely the influence of Current Ratio (CR), Total Assets Turnover (TATTOO), Price Earnings Ratio (PER) and Return on Assets (ROA) to Profit Changes (PC) meets the fit criteria, or 4 independent variables have significant influence towards profit change analysis that based on fair value.

\section{Test $t$}

The t-statistical test is used to examine the relationship between the dependent variable and the independent variable (see Christiano, Tommy, \& Saerang, 2014). This test is to know whether one variable has got influence toward another variable, by assuming the other independent variables are constant.

Table 9

The t-statistical test

\begin{tabular}{lcc}
\hline \multicolumn{1}{c}{ Variable } & SIG & Description \\
\hline Current Ratio & 0,045 & Significant \\
Total Asset Turnover & 0,048 & Significant \\
\hline
\end{tabular}


Price Earnings Ratio

0,016

Significant

Return on Assets

0,256

Not Significant

The examination of Current Ratio Hypothesis towards profit changes

The t-count value of Current Ratio variable has been known in the amount of 2.060 with sig $0.045<(\alpha) 0,05$ or in standard significant less than 0,05 , or in the amount of 0,045 . H0 was not rejected. It means Current Ratio has got significant influence towards profit value that based on fair value.

The examination of Total Asset Turnover hypothesis towards profit change

The t-count value of Total Asset Turnover variable has been in the amount of 2.033 with sig $0.048<(\alpha) 0,05$ or in standard significant less than 0,05 , or in the amount of 0,048. H0 was not rejected. It means, based on fair Value, Current Ratio has a significant influence towards profit change.

The examination of the Price Earnings Ratio hypothesis towards profit changes

The t-count value of the Price Earnings Ratio variable has been in the amount of 2.496 with sig $0.016<(\alpha) 0,05$, or in standard significant less than 0,05 , or in the amount of 0,016 . H0 was not rejected. It means, based on fair Value, Price Earnings Ratio has a significant influence towards profit change.

The examination of Return on Assets hypothesis towards profit changes

The t-count value of Return on Asset variable has been known in the amount of 1.151 with sig $0.256>(\alpha) 0.05$, or in a significant level of more than 0.05 or in the amount of 0.256 . H0 was successfully rejected. It means, based on Fair Value, the Return on Assets has no significant influence toward profit changes on the property company, real estate and building construction that have been listed in the Indonesia Stock Exchange.

\subsection{Discussion}

Current Ratio Hypothesis (H1) towards profit changes was accepted since the current ratio, based on fair value, has got positive influence toward profit changes of a property company, real estate, and building construction, that have been listed in Indonesia stock exchange. This is shown by a positive regression coefficient value. The amount number of the value is 0.112 , and the significance value of the $t$-test, that is less than 0.05 has amount number of 0.045 . The result of this research shows that Current Ratio can be used to predict future profit changes. The results of this research support research conducted by Susanti \& Widyawati (2016), that stated: Current Ratio has influenced profit changes and can predict future profit changes. However, this research does not support previous research that conducted by Pangkong, Lambey, \& Affandi (2017). They stated that Current Ratio does not have the ability to predict significant profit changes.

Total Asset Turnover Hypothesis (H2) towards profit change is accepted since the Total Assets Turnover has found the effect to profit changes positively, in the fair-value-based. This is shown by a positive regression coefficient value. The amount is 0.632 and the significance $t$-test value, that is less than 0.05 , is 0.048 . The results of this study show that the higher Total Assets Turnover company, the higher profit change company obtained. The result of this research, at this point, is not in line with the research conducted by Susanti \& Widyawati (2016) and Pangkong, Lambey, \& Affandi (2017). They stated that the Total Asset Turnover has not significant influence towards profit changes.

Price Earnings Ratio Hypothesis (H3) towards profit change is accepted since the Price Earnings Ratio influenced profit changes, in the fair-value-based. This is indicated by a negative regression coefficient value. It is 0.026 , and the significance t-test is greater than 0.05, that is in the amount of 0.016. Price Earnings Ratio has got positive and significant influence towards profit changes. It means, Price Earnings Ratio can be used to measure the profit change. The positive Price Earnings Ratio influence towards profit change indicates that the company with a good condition of Price Earnings Ratio has got potential attractiveness for investors.

Return on Assets Hypothesis (H4) towards profit change is rejected since the Return on Asset, based on fair Value, has got negative influence towards profit change. This is indicated by the negative regression coefficient value, that is 2.453, and the t-test significance value is greater than 0.05, that is in the amount of 0.265 . Return on Asset has got negative influence and not is significant towards profit changes. This means Return on Assets cannot be used to measure profit change. The negative influence of Return on Assets towards profit change indicates that whether a Company has got good Return on Assets condition, or bad Return on Assets condition, is not influencing the potential attractiveness for investors. In this point, the results of this study do not support the research conducted by Sujarwo

Pattiasina, Pattiasina, V., Sejati, F. R., Seralurin, Y. C., Batilmurik, R. W., \& Aziz, M. A. A. (2018). The impact of financial ratios towards profit changes. International Research Journal of Management, IT and Social Sciences, 5(5), 1-16. https://doi.org/10.21744/irjmis.v5n5.275 
and Engrossed (2015). They stated that the return on asset influenced profit changes and can be used to predict future profit changes (see Wibowo \& Pudjiati, 2011).

Simultaneously Hypothesis (H5) of Current Ratio, Total Asset Turnover, Price Earnings Ratio, and Return on Assets, towards profit change is accepted. Based on fair Value, it has got influence towards profit change towards Property Company, real estate, and building construction. The statement is based on the determination coefficient (R2) obtained. The amount is 0.160 . The relationship between the dependent and independent variables is $16 \%(0.160 \mathrm{x}$ $100 \%)$.

\section{Conclusion}

Based on the results discussed above, The researchers draw some conclusions, namely: 1) Current ratio, based on fair Value, has got influence towards profit changes of Sub Sectors Property company, real estate, and building construction, that were listed on the Indonesia Stock Exchange. 2) Total Assets Turnover, based on fair Value, has got influence towards profit changes of Sub Sectors Property Company, real estate, and building construction, that were listed on the Indonesia Stock Exchange. 3) Price Earnings Ratio, based on fair Value, has got influence towards profit changes of Sub Sectors Property Company, real estate, and building construction, that were listed on the Indonesia Stock Exchange. 4) Return on Assets, based on fair Value, has no influence towards profit change towards profit changes of Sub Sectors Property Company, real estate, and building construction, that were listed on the Indonesia Stock Exchange. 5) Current Ratio, Total Asset Turnover, Price Earnings Ratio, and Return on Assets, based on fair Value, have influenced profit changes simultaneously.

Based on the results of the study and the conclusions that have been drawn the researchers suggest following things: 1) Companies' managers and investors should be more careful in assessing company's financial statements, especially in company assets accounting. The company in this study was examined its profit change through the current ratio, Total Assets Turnover, Price Earnings Ratio and Return on Assets. The examination was done to know the strengths and the weaknesses of the company. 2) For future researchers; they are expected to add more sample, to change the research sector, and to add a variable (rentability ratio) since there is a possibility that better conclusions will be generated by including more variables.

Conflict of interest statement and funding sources

The authors declared that they have no competing interest. The study was financed by themselves.

Statement of authorship

The authors have a responsibility for the conception and design of the study. The authors have approved the final article.

\section{Acknowledgments}

The authors thank the editor of IRJMIS for their support, valuable time, advice, and accepted this article. 


\section{References}

Aprilia, F., \& Andayani, A. (2017). Analisis Rasio Keuangan Untuk Memprediksi Perubahan Laba Pada Perusahaan Kimia di BEI. Jurnal Ilmu dan Riset Akuntansi, 5(11).

Argilés, J. M., \& Slof, E. J. (2001). New opportunities for farm accounting. European Accounting Review, 10(2), 361383.

Christiano, M., Tommy, P., \& Saerang, I. (2015). Analisis Terhadap Rasio-Rasio Keuangan Untuk Mengukur Profitabilitas Pada Bank-Bank Swasta Yang Go Public Di Bursa Efek Indonesia. Jurnal EMBA: Jurnal Riset Ekonomi, Manajemen, Bisnis dan Akuntansi, 2(4).

Dechow, P. M., Myers, L. A., \& Shakespeare, C. (2010). Fair value accounting and gains from asset securitizations: A convenient earnings management tool with compensation side-benefits. Journal of accounting and economics, 49(1-2), 2-25.

Egam, G. E., Ilat, V., \& Pangerapan, S. (2017). Pengaruh Return on Asset (ROA), Return on Equity (ROE), Net Profit Margin (NPM), dan Earning Per Share (EPS) terhadap Harga Saham Perusahaan yang Tergabung dalam Indeks LQ45 di Bursa Efek Indonesia Periode Tahun 2013-2015. Jurnal EMBA: Jurnal Riset Ekonomi, Manajemen, Bisnis dan Akuntansi, 5(1).

Ghozali, I. (2009). Ekonometrika Teori, Konsep dan Aplikasi dengan SPSS 17. Semarang: Badan Penerbit Universitas Diponegoro.

Ghozali, I. (2016). Aplikasi Analisis Multivariete IBM SPSS 23. Semarang. Universitas Diponegoro.

Hadi, A., Handajani, L., \& Putra, I. N. N. A. (2018). Financial Disclosure based on Web-ICT Determinants: Its Implications for Local Government Financial Performance in Indonesia. International Research Journal of Management, IT and Social Sciences (IRJMIS), 5(1), 72-85.

Hanafi, D. M. M. MBA \& Prof. Dr. Abdul Halim, MBA, Akt. Analisis Laporan Keuangan.

Hermanda, R., \& Amanah, L. (2016). Pengaruh Rasio Keuangan Terhadap Perubahan Laba. Jurnal Ilmu dan Riset Akuntansi, 4(1).

Indonesia, I. A. (2013). Standart Akuntansi Keuangan-Entitas Tanpa Akuntabilitas Publik. IAI. Jakarta Martono. Dan D. Agus Harjito. 2005. Manajemen Keuangan.

Junaedi, A. T., \& Helen, H. (2017). Analisis pengaruh current ratio (cr), debt to equity ratio (der), return on equity (roe) dan price to earning ratio (per) terhadap harga saham pada sektor perkebunan di bursa efek indonesia (bei). Procuratio (Jurnal Ilmiah Manajemen), 4(4), 531-540.

Karuniawati, H. F. (2016). Pengaruh Rasio Keuangan Terhadap Perubahan Laba pada Bank Bca Darmo Surabaya. Jurnal Ilmu dan Riset Akuntansi, 3(1).

Lisa, O., \& Hermanto, B. (2018). The effect of tax amnesty and taxpayer awareness to taxpayer compliance with financial condition as intervening variable. International Research Journal of Management, IT and Social Sciences (IRJMIS), 5(2), 227-236.

Noch, M. Y., \& Rasyid, A. (2012). Metodologi Penelitian: Untuk Manajemen dan Akuntansi.

Pangkong, C. M., Lambey, L., \& Afandi, D. (2017). Dampak Rasio Aktivitas Dan Rasio Likuiditas Terhadap Perubahan Laba Berbasis Fair Value (Studi Empiris Pada Perusahaan Sub Sektor Property Dan Real Estate Yang Terdaftar Di Bursa Efek Indonesia). Jurnal EMBA: Jurnal Riset Ekonomi, Manajemen, Bisnis dan Akuntansi, 5(2).

Santosa, P. B. (2005). Analisis Statistik dengan Microsoft Excel dan SPSS. Yogyakarta: Andi.

Siahaan, H. (2007). Analisis Kritis atas Laporan Keuangan. Jakarta: PT Raja Grafindo Persada.

Suardana, I. B. R., Astawa, I. N. D., \& Martini, L. K. B. (2018). Influential Factors towards Return On Assets and Profit Change. International Journal of Social Sciences and Humanities (IJSSH), 2(1), 105-116.

Sujarwo, R. A., \& Asyik, N. F. (2016). Pengaruh rasio keuangan terhadap perubahan lapa pada perusahaan otomotif di bursa efek indonesia. Jurnal Ilmu dan Riset Akuntansi, 4(10).

Suliyanto, D. (2011). Ekonometrika Terapan: Teori dan Aplikasi dengan SPSS. Penerbit Andi: Yogyakarta.

Susanti, I. D. N., \& Widyawati, D. (2016). Pengaruh Kinerja Keuangan Terhadap Perubahan Laba Perusahaan Farmasi di Bursa Efek Indonesia. Jurnal Ilmu dan Riset Akuntansi, 5(3).

Wahyuni, E. T. (2013). Konvergensi Standar Pelaporan Keuangan Internasional (IFRS).

Warnoso, D. S. (2011). Adopsi Standar Akuntansi IFRS. (I. Natalia, Ed.). Yogyakarta: AB Publisher.

Wibowo, H. A., \& Pujiati, D. (2011). Analisis Rasio Keuangan Dalam Memprediksi Perubahan Laba Pada Perusahaan Real Estate Dan Property di Bursa Efek Indonesia (BEI) dan Singapura (SGX). The Indonesian Accounting Review, 1(02), 155-178.

Pattiasina, Pattiasina, V., Sejati, F. R., Seralurin, Y. C., Batilmurik, R. W., \& Aziz, M. A. A. (2018). The impact of financial ratios towards profit changes. International Research Journal of Management, IT and Social Sciences, 5(5), 1-16. https://doi.org/10.21744/irjmis.v5n5.275 


\section{Biography of Authors}

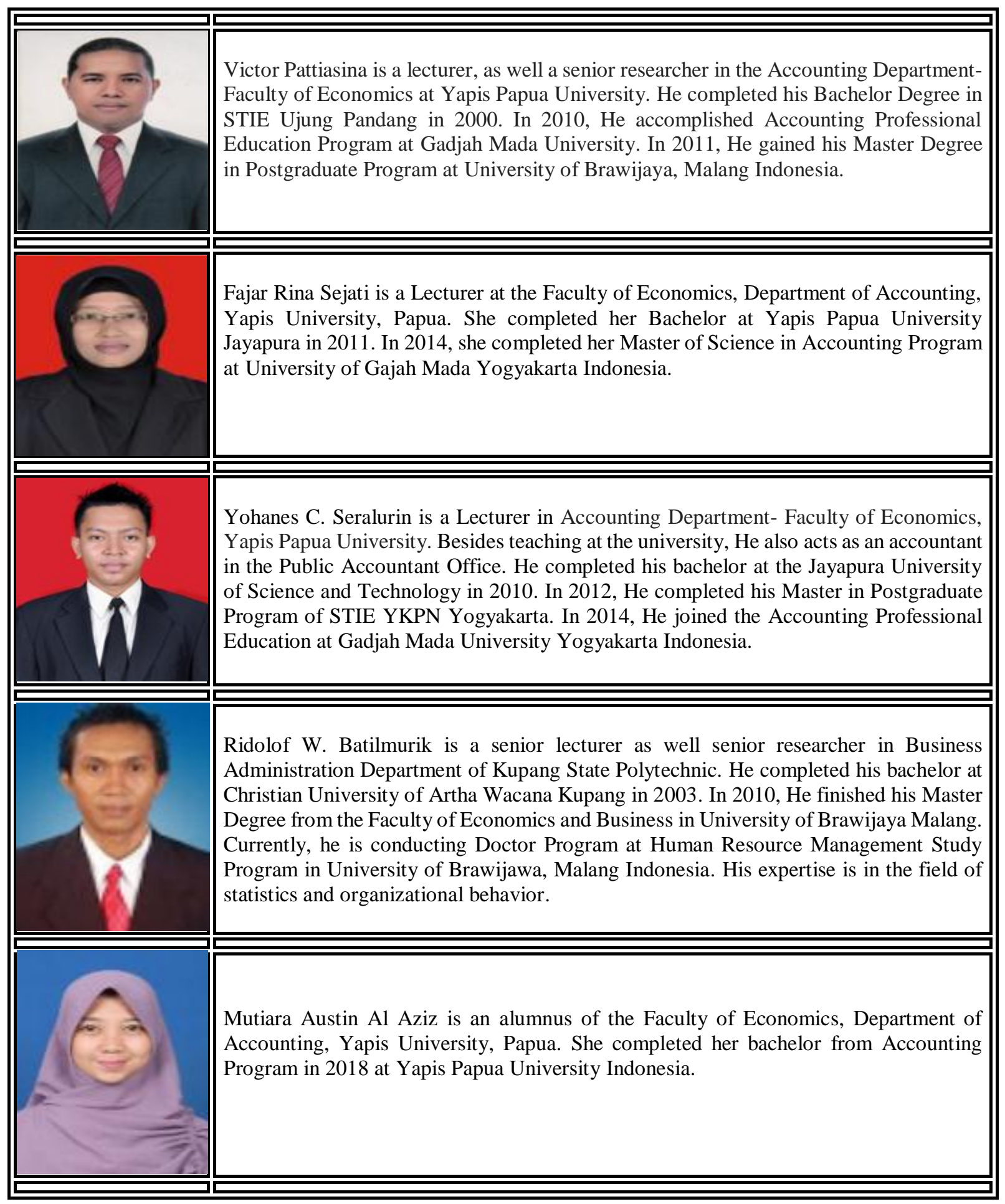

